\title{
Persepsi Kesehatan Dan Well-Being Penderita Hipertensi Di Desa Ritabel
}

\author{
Thersya Miranda Batlajery \\ Program Studi Ilmu Keperawatan Fakultas Kedokteran dan Ilmu Kesehatan \\ Universitas Kristen Satya Wacana \\ thersyabatlajery@gmail.com \\ Simon Pieter Soegijono \\ Universitas Kristen Indonesia Maluku \\ petersoegijono@gmail.com (correspondingauthor)
}

\begin{abstract}
Abstrak
Persepsi merupakan proses yang panjang mulai dari penginderaan hingga pemberian makna, baik itu mengenai kesehatan itu sendiri maupun tentang psychological well-being. Tujuan dari penelitian ini adalah mengetahui bagaimana persepsi kesehatan dan well-being penderita hipertensi di Desa Ritabel. Penelitian ini menggunakan pendekatan kualitatif dengan studi fenomenologi. Teknik pengumpulan data menggunakan observasi, wawancara dan dokumentasi. Keabsahan data menggunakan triangulasi sumber data. Hasil dari penelitian ini meliputi ditemukan 4 tema yaitu pemaknaan konsep sehat dan sakit, dimensi sehat (secara mental, spiritual dan ekonomi), kesejahteraan, kepuasan hidup dan hubungan yang positif dan penentuan tujuan hidup serta pengembangan potensi diri sehingga dapat disimpulkan bagi masyarakat didesa Ritabel persepsi tentang sehat dan sakit berpulang pada diri sendiri bagaimana cara berpikir masing-masing sedangkan kesejahteraan, partisipan memahami dalam bentuk kasih sayang untuk keluarga, tetangga dan semua orang dan menjalani hidupnya dengan bahagia.
\end{abstract}

Kata Kunci: persepsi kesehatan, well-being, hipertensi.

\section{Pendahuluan}

Menurut Robbins dan Judge (dalam Sudarsono, 2016) persepsi merupakan proses seseorang menata serta mengintepretasikan efek-efek sensorinya untuk memberi makna kepada lingkungannya. Sedangkan Budioro (dalam Primanita, 2011) berpendapat bahwa persepsi adalah suatu proses psikologis dasar yang berpengaruh terhadap terbentuknya ingatan, pikiran serta proses pembelajaran. Walgito (dalam Sudaryanto, 2008) menyatakan, bahwa persepsi individu diawali dengan jalan pengindraan yakni terbentuk dari penerimaan struktur oleh sesorang 
lewat alat indera-inderanya. Hal ini diperkuat oleh Rahmat (dalam Sudaryanto, 2008) yang mengatakan bahwa persepsi adalah perjalanan suatu obyek/peristiwa yang didapatkan dengan mencari informasi serta mengartikan pesan-pesan. Berdasarkan pengertian di atas dapat disimpulkan bahwa persepsi adalah perjalanan suatu obyek/peristiwa yang didahului oleh penginderaan dan diartikan melalui efek-efek sensori serta berpengaruh terhadap terbentuknya ingatan, pikiran serta proses pembelajaran.

Undang-undang No. 36 tahun 2009 (dalam Adliyani dkk, 2015) tentang kesehatan, menerangkan bahwa kesehatan merupakan keadaan sehat, baik secara fisik, mental, spritual maupun sosial yang memungkinkan setiap orang untuk hidup produktif secara sosial dan ekonomis. Menurut Organisasi Kesehatan Dunia atau WHO (dalam Chamidah, 2010) sehat merupakan keadaan tubuh yakni fisik, mental, ataupun sosial tidaklah berkekurangan serta tidak mengalami sakit maupun lemah. Menurut Maulana (dalam Saputri, 2016) kesehatan merupakan aspek yang diperlukan dalam meningkatkan kualitas hidup seseorang, baik sosial maupun ekonomi. Sehingga dapat disimpulkan bahwa kesehatan merupakan keadaan tubuh secara fisik, mental, dan sosial tidak dalam keadaan sakit serta merupakan aspek yang diperlukan dalam meningkatkan kualitas hidup seseorang, baik sosial maupun ekonomi.

Dari pengertian kedua konsep mengenai persepsi dan kesehatan diatas maka didapati pemahaman mengenai persepsi kesehatan, yaitu merupakan perjalanan suatu obyek/peristiwa yang didahului oleh penginderaan dan diartikan melalui efek-efek sensori serta yang berkaitan dengan keadaan sehat dan sejahtera seseorang baik secara fisik, mental, spiritual maupun sosial dan merupakan aspek yang diperlukan dalam meningkatkan kualitas hidup manusia baik sosial maupun ekonomi. Setiap individu memiliki persepsi/asumsi tentang kesehatan yang berbeda-beda, hal ini dipengaruhi oleh pekerjaan, suku bangsa maupun tingkat pendidikan sehingga perlu dilakukannya penelitian tentang persepsi kesehatan (Sari, 2015). Untuk menjelaskan persepsi kesehatan terdapat beberapa teori yang biasa digunakan yaitu Health Promotion Model dan Health Belief Model. 
Health promotion model dikemukakan oleh Pender tahun 1984 dan berpusat pada tiga faktor yakni: yang pertama faktor-faktor modifikasi meliputi variabel pengaruh interpersonal, karakteristik demografi, karakteristik biologi, faktor situasi dan faktor tingkah laku dan faktor yang kedua yakni faktor persepsi kognisi yang meliputi variabel berharganya kesehatan, asumsi/persepsi mengenai kekuatan diri, asumsi/persepsi mengenai pemeriksaan kesehatan, asumsi/persepsi mengenai status kesehatan, pengertian sehat, dan asumsi/persepsi tentang kegunaan tindakan promosi kesehatan serta faktor yang terakhir atau yang ketiga yakni faktor persepsi hambatan perilaku promosi kesehatan yang berfokus untuk menjelaskan penyebab seseorang mengikuti kegiatan promosi kesehatan (Sudaryanto, 2008). Contohnya, pada penelitian Wibowo dan Suryani (2013) dinyatakan bahwa setelah dilakukan promosi kesehatan kepada ibu-ibu rumah tangga tentang penggunaan monosodium glutamat (MSG) didapatkan hasil promosi kesehatan melalui metode buku saku dan audio visual dapat peningkatan pengetahuan ibu-ibu rumah tangga mengenai penggunaan monosodium glutamat.

Health belief model dikembangkan oleh Becker pada tahun 1974 dan dipakai guna mengetahui tindakan individu tentang kepatuhan dan pencegahan penyakit (dalam Nurfitriyana, 2015). Model ini menekankan bahwa persepsi individu terhadap kemujaraban dan kerentanan pengobatan bisa berpengaruh terhadap pilihan perilaku kesehatan individu (Setiyaningsih, 2016). Contohnya penderita hipertensi meyakini bahwa jika belum merasakan dampak dari penyakit ini, maka penyakit hipertensi bukan merupakan penyakit yang berbahaya sehingga muncullah sikap/perilaku yang tidak mematuhi anjuran medis (non compliance) (Nurfitriyana, 2015). Penyebab perilaku seperti ini adalah keyakinan dari penderita bahwa penyakit hipertensi bukan merupakan penyakit berbahaya (Nurfitriyana, 2015).

Menurut Situmorang (2015) hipertensi atau biasa di kenal di masyarakat awam dengan istilah darah tinggi merupakan suatu keadaan meningkatnya tekanan darah individu melewati batasan normalnya. Hipertensi biasanya dijuluki sebagai sillent killer atau pembunuh diam-diam, sebab hipertensi merupakan penyakit yang tidak diketahui gejalanya sebagai pengingat bagi penderita 
(Situmorang, 2015). Pada buku aplikasi keperawatan berdasarkan diagnosa medis dan NANDA (North American Nursing Diagnosis Association) NIC (Nursing Intervention Classification) NOC (Nursing Outcome Classification) (dalam Nurarif, 2015) hipertensi merupakan peningkatan tekanan darah sistolik sedikitnya $140 \mathrm{mmHg}$ atau tekanan diastolik sedikitnya $90 \mathrm{mmHg}$.

Penyakit tidak menular (PTM) salah satunya hipertensi dapat membunuh tiga puluh enam juta jiwa per tahunnya dan merupakan penyebab kematian di seluruh dunia (Profil Kesehatan Maluku, 2014). Berdasarkan hasil Riset Kesehatan Dasar tahun 2007 prevelensi hipertensi di negara Indonesia meningkat mencapai 31,7 persen dari total penduduk dewasa (Riset Kesehatan Dasar, 2007). Pada tahun 2013 prevalensi hipertensi di negara Indonesia mengalami penurunan menjadi 25,8 persen dari total penduduk dewasa (Riset Kesehatan Dasar, 2013). Khusus di Provinsi Maluku pada tahun 2007 prevalensi hipertensi mencapai 29,3 persen (Riset Kesehatan Dasar, 2007) dan tahun 2013 menurun menjadi 24,1 persen (Riset Kesehatan Dasar, 2013). Dari data Ringkasan Eksekutif Data dan Informasi Kesehatan Provinsi Maluku tahun 2014 didapati prevalensi hipertensi berdasarkan diagnosis tenaga kesehatan di Indonesia, provinsi Maluku mencapai 6,6 persen dari total prevalensi hipertensi di Indonesia 9,4 persen dan data pada Profil Kesehatan Maluku tahun 2014 Kabupaten Maluku Tenggara Barat merupakan daerah dengan prevalensi hipertensi mencapai 7,2 persen dari total penduduk dewasa di Provinsi Maluku.

Hipertensi dapat membahayakan penderita karena saat tertentu bisa menyebabkan komplikasi pada jantung, mata, otak, penbuluh darah, ginjal maupun organ vital lainnya (Primanita, 2011). Berdasarkan data Global Health Risk tahun 2004 (dalam Widianingrum, 2012) sebanyak 12,8\% hipertensi adalah penyebab utama kematian. Penyakit hipertensi ini disebabkan oleh faktor gaya hidup masyarakat yang tidak sehat, seperti terus menerus mengkonsumsi makanan siap saji yang mengandung pengawet, mengkonsumsi lemak berlebih dan makanan yang mempunyai kandungan garam yang sangat tinggi, kurangnya aktivitas fisik seperti berolahraga dan merokok serta faktor emosional yakni stres sehingga perlu untuk mengontrol stres (Suoth, 2014). 
Menurut Al-Firdaus (dalam Furqon, 2016) keadaan emosional sesorang yang berlebihan bisa berpengaruh terhadap penyakit hipertensi yang dideritanya, dilihat dari bagaimana aspek psikologis mempunyai pengaruh yang besar terhadap perkembangan penyakitnya. Menurut Furqon dan Nafiah (2016), keadaan psikologis individu yang berlebihan atau sedang tidak normal bisa menimbulkan hipertensi, emosi negatif individu yang kuat dapat berpengaruh terhadap sistem imun tubuhnya. Adanya ikatan antara hipertensi dan stres dibuktikan melalui aktivitas saraf simpatis, saat seseorang stres mengakibatkan adanya adrenalin ke dalam aliran darah, hal ini yang menjadi penyebab terjadinya kenaikan tekanan darah (Situmorang, 2015). Menurut Sue Hichlift (dalam Vitahealth, 2005) stres bisa mengancam kesehatan jasmani maupun emosional. Bila individu selalu dalam keadaan seperti ini, maka akan tetap meningkat tekanan darahnya (dalam Situmorang, 2015).

Seperti yang sudah dibahas sebelumnya, masalah psikologis seperti stres akan memengaruhi tekanan darah seseorang sehingga beresiko terjadinya hipertensi (Furqon, 2016). Tapi apabila penderita hipertensi mempunyai kondisi psychological well-being yang baik maka potensi dalam dirinya dapat dikembangkan dan penderita juga sanggup ciptakan lingkungan yang sesuai dengan keadaan fisik penderita, sehingga dapat dikontrol dengan baik tekanan darahnya (Furqon, 2016).

Kesejahteraan (well-being) dapat diartikan sebagai kualitas hidup individu maupun masyarakat (Utami, 2012). Dari perdebatan para ahli filsafat mengenai kehidupan yang baik maka didapati kesimpulan yakni kehidupan yang baik adalah kebahagiaan (Utami, 2012). Individu dikatakan sejahtera apabila individu mampu menerima kehidupannya, mempunyai hubungan positif dengan orang lain, sanggup menghadapi masalah, sanggup untuk mengembangkan potensi yang dimiliki secara terus-menerus, mampu menetapkan tujuan hidupnya dan mengetahui makna hidupnya pada waktu sekarang dan dahulu, serta sanggup membuat lingkungan yang cocok dengan keadaan tubuh individu (Furqon, 2016).

Hasil penelitian Sipayung (2015) menunjukan bahwa terdapat kesejahteraan subyektif pada remaja awal penderita kanker. Hal ini dilihat dari 
dua orang remaja awal penderita kanker di Rumah Sakit Kanker "Dharmais" Jakarta Barat yang merasa puas terhadap hidupnya, sehingga muncullah afek positif (bersemangat dan bahagia) yang lebih besar melebihi afek negatif (gugup, malu, jenuh dan takut) disebabkan oleh dimilikinya dukungan sosial yang baik sehingga menyebabkan kedua subjek merasa bangga, puas serta sejahtera. Dari penelitian inilah dapat diketahui bahwa adanya hubungan antara well-being dengan penyakit.

Semua penduduk yang ada di Indonesia tersebar mulai dari ujung Barat sampai ujung Timur, dimulai dari Sumatera sampai Papua yakni dengan kondisi geografis yang sangat berbeda-beda dan dipengaruhi oleh budaya dan pemahaman yang berbeda-beda (Widiastuti, 2013). Konsep sehat sakit setiap daerah juga berbeda-beda karena keterbatasan informasi yang diperoleh masyarakat. Di daerah Maluku khususnya di Kecamatan Tanimbar Utara. Kota Larat, masyarakat masih menganggap hipertensi bukanlah penyakit yang serius karena tidak langsung merasakan dampak dari penyakit ini.Penelitian ini bertujuan untuk mengetahui bagaimana persepsi kesehatan dan well being penderita hipertensi di Desa Ritabel.

\section{Metode}

Penelitian ini menggunakan pendekatan kualitatif dengan jenis studi fenomenologi. Teknik pengumpulan datanya dilakukan dengan wawancara serta dokumentasi. Wawancara dilakukan secara terencana dan ada kesepakatan sebelumnya dengan partisipan dan menggunakan inform consent (lembar persetujuan) serta panduan wawancara sebagai alat pengumpul data. Langkahlangkah analisas terdiri dari: pengumpulan data, reduksi data, penyajian data dan penarikan kesimpulan (Ningrum, 2015). Untuk memvalidasi data, digunakan triangulasi sumber data.

Penelitian dilaksanakan di Desa Ritabel Kecamatan Tanimbar Utara, Kabupaten Maluku Tenggara Barat (MTB) Provinsi Maluku pada bulan Agustus 2017. 


\section{Hasil dan Pembahasan}

Partisipan dalam penelitian ini terdiri dari 5 orang, berikut datanya:

Tabel 1: Data Diri Partisipan

\begin{tabular}{llll}
\hline No & Nama & Umur & Pekerjaan \\
\hline 1 & Ny. L & 48 tahun & Petani \\
\hline 2 & Tn. L & 65 tahun & Pensiunan guru \\
\hline 3 & Ny. M & 42 tahun & Petani \\
\hline 4 & Ny. E & 43 tahun & Petani \\
\hline 5 & Tn. F & 50 tahun & Petani dan nelayan \\
\hline
\end{tabular}

Berdasarkan analisa terhadap data dari kelima partisipan dalam penelitian ini, ditemukan 4 kategori, yaitu pemaknaan konsep sehat dan sakit, dimensi sehat (secara mental, spiritual dan ekonomi), kesejahteraan, kepuasan hidup dan hubungan yang positif dan penentuan tujuan hidup serta pengembangan potensi diri. Berikut adalah penjelsan dari masing-masing kategori.

1. Pemaknaan konsep sehat dan sakit.

Dalam kategori ini, partisipan memahami bahwa makna sehat dan sakit berpulang pada diri kita sendiri, jika kita berpikir kita sakit maka kita akan sakit begitu pula sebaliknya. Sehat berarti didalam tubuh tidak terdapat penyakit dan bisa berjalan kemana saja.

“...Sehat kembali kepada diri kita sendiri, jika kita berpikir diri kita sehat maka kita tetap sehat sebaliknya jika kita berpikir kita sakit maka kita akan sakit...”(P1)

“...Didalam tubuh tidak ada penyakit tetapi kalau ada penyakit berarti tidak sehat...”(P2)

“...Tidak ada penyakit didalam tubuh dan bisa berjalan kemana-mana saja..” (P3)

“...Sehat berarti tidak ada penyakit satu pun dalam tubuh kita, intinya tidak sakit...” (P4)

“...Sehat berarti tidak sakit dan benar-benar tidak ada penyakit satu pun di dalam tubuh..."(P5)

Pemahaman ini sejalan dengan hasil dari penelitiannya Budijanto dan Roosihermlatie (2006) yang menyatakan bahwa sehat berarti keadaan jasmani, rohani dan fisik tidak terjadi gangguan dan biasa menjalankan tugas. Hal ini juga sesuai dengan definisi sehat menurut Organisasi Kesehatan Dunia (WHO) bahwa sehat merupakan keadaan tubuh secara fisik, mental, maupun sosial tidak 
berkekurangan serta tidak mengalami sakit maupun lemah (dalam Chamidah, 2010). Berdasarkan definisi sehat tersebut maka cirinya orang yang sehat menurut partisipan adalah sempurna secara fisik maupun mental, tidak pikun dan wajah tidak pucat (karena wajah pucat adalah pertanda sakit).

“...Kesehatan mereka bagus tidak terganggu penyakit. Mereka tidak sakit dan bisa pergi di kabun..."(P1)

“...Orang tidak cacat, tidak gila, tidak pikun, memiliki organ tubuh yang lengkap...”(P2)

“...Ciri-ciri orang sehat itu wajahnya tidak pucat karena yang pertama dilihat orang itu wajah sehingga jika wajah pucat saja orang sudah tahu sedang sakit dan bisa jalan kemana-mana...,"(P3)

“...Wajah mereka tidak pucat, bisa jalan kemana-mana, tidak ada penyakit dalam tubuh...”(P4)

“...Ciri-ciri orang sehat itu wajah segar, bisa pergi ke kebun, memancing dan tidak minum obat apapun..." (P5)

Pemahaman ini sejalan dengan ciri-ciri sehat menurut WHO (dalam Harjati, dkk, 2012) yang menyatakan bahwa orang yang sehat adalah yang memiliki kondisi yang sempurna secara fisik, mental, sosial dan hanya bebas dari penyakit, cacat dan kelemahan.

Untuk konsep sakit, partisipan menanggapi sebagai suatu gangguan dalam tubuh, baik fisik maupun mental.

“...Ada banyak macam sakit karena diserang penyakit dan sakit jiwa. Jadi sakit itu merupakan gangguan dalam tubuh, baik fisik maupun mental.... ”(P2)

“...Adanya penyakit dalam tubuh kita...”(P3)

“...Sakit itu ada gangguan dalam tubuh baik itu fisik atau jiwa...”(P5)

Pemahaman partisipan disini sejalan dengan pengertian sakit oleh Perkins (dalam Sani, 2011) yang menyatakan bahwa sakit merupakan kondisi tidak menyenangkan yang dialami individu sehingga mengakibatkan terganggunnya aktifitas sehari-hari yakni secara jasmani, rohani dan sosial. Sebagai cirinya orang yang sakit memiliki wajah pucat, tidak dapat beraktivitas, banyak pikiran, badan lemas, menangis kesakitan dan suhu tubuh tidak normal.

“...Badannya lemas, suhu tubuh tidak normal, muka pucat Sakit karena tidak menjaga kesehatan...”(P2) 
“...Ciri-cirinya itu wajah pucat, tidak bisa beraktifitas, suhu tubuh panas dingin ... ”(P3)

“...Wajah pucat, tidak bisa pergi kemana-mana...”(P4)

“...Badan lemas dan pucat...”(P5)

Pemahaman ini sejalan dengan ciri-ciri orang sakit yang sampaikan Wongsohardjono (2012) yakni seorang pasien menunjukan ciri-ciri wajah pucat, berat badan menurun, konjungtiva pucat, terlihat lemah, pasien ini sudah sebulan dirawat dan telah mondok selama satu minggu.

Partisipan juga menuturkan cara yang dilakukannya untuk menjaga kesehatan yaitu dengan cara mandi dua kali sehari, mengontrol makanan dan minuman yang dikonsumsi, istirahat yang cukup serta menjaga kebersihan lingkungan tempat. Mereka mengatakan untuk mengatasi sakit dilakukan dengan memeriksakan diri ke dokter atau puskesmas terdekat, tidak terlalu banyak pikiran, beristirahat di rumah, membeli obat, harus bergerak dan berjemur di sinar matahari pagi.

“...Kita harus menjaga makan dan minum, menjaga lingkungan rumah harus rapih walaupun rumah tidak besar tetapi yang penting bersih dan rapih, unuk mengatasi sakit jangan terlalu banyak pikiran dan banyak bergerak serta memeriksakan diri ke rumah sakit atau memanggiil bidan untuk datang periksa di rumah... ”(P1)

“...Cara kita menjaga kesehatan dengan cara mandi 2 kali sehari, menjaga makan dan minum makan makanan yang bergizi, untuk mengatasi sakit kita harus ke dokter atau puskesmas terdekat untuk kontrol, cara itu dilakukan karena dokter, bidan, mantri lebih tahu mengenai penanganan dan pemberian obat dari pada partisipan. Cara lain tergantung sakit nya jika sakit yang diderita karena kerasukan atau kuasa gelap, maka ke dukun/paranormal untuk berobat... "(P2)

“...Kita menjaga kebersihan makanan dan minuman serta lingkungan tempat kita tinggal, untuk mengatasi sakit kita harus kuatkan diri dan bergerak supaya keringat dan penyakit itu hilang, berjemur dibawah sinar matahari dan periksakan diri ke puskesmas. Cara itu dilakukan supaya tidak sakit. Jika tidak maka sakit kita akan semakin

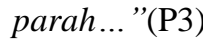

“...Jika pulang kebun jangan lupa mandi, kemudian makan walaupun seadanya tetapi bersih dan jangan lupa istirahat dan untuk mengatasi sakit dengan cara kita harus melawan penyakit itu dengan bergerak jangan tidur-tidur, membeli obat diwarung jika tidak sembuh periksakan ke puskesmas/dokter setempat, apabila ada obat tradisional seperti daun-daunan atau apapun harus kita coba agar cepat sembuh... ’(P5)

Pemahaman ini sejalan dengan penelitian yang dilakukan oleh Budijanto dan Roosihermiatie (2006) yang menyatakan masyarakat lebih tertarik membeli obat-obatan sendiri di warung atau toko obat-obatan terdekat, jika tidak kunjung 
sembuh baru mereka pergi ke pelayanan tenaga kesehatan, seperti dokter swasta, puskesmas, maupun rumah sakit. Selain itu ada cara lain yang dapat dilakukan, yakni jika sakit yang diderita karena kerasukan atau pengaruh kuasa kegelapan, maka harus diobati oleh dukun/paranormal dan apabila terdapat obat tradisional seperti daun-daunan harus dicoba agar cepat mengalami kesembuhan. Pemahaman ini sejalan dengan buku yang ditulis oleh Hasbullah, dkk (2014) yang menyatakan praktek perdukunan telah menjadi kebiasaan turun-temurun, apabila telah berobat ke dokter, tetapi tidak mengalami penyembuhan, maka masyarakat akan pergi mencari pengobatan alternatif yakni ke dukun. Budijanto dan Roosihermiatie (2006) juga menambahkan bahwa masyarakat juga menggunakan pengobatan tradisional seperti pijat urut dan jamu-jamuan tradisional apabila pengobatan medis tidak bisa menolong.

2. Dimensi sehat (secara mental, spiritual dan ekonomi).

Dalam kategori ini, partisipan menunjukkan pemahaman bahwa sehat memiliki dimensi mental, spiritual dan ekonomi. Dalam dimensi mental, partisipan mengatakan bahwa kesehatan merupakan sehat jiwa dan pikiran, tidak gila, bisa berpikir jenih serta mengetahui mana yang tidak baik dan yang baik. Partisipan juga menambahkan bahwa seseorang mengalami gangguan mental (gila) karena banyak pikiran yang tidak bisa dikendalikannya. Untuk mengatasi gangguan mental sebaiknya tidak boleh banyak berpikir, jika ada masalah sebaiknya diutarakan kepada orang lain (tidak disimpan dalam hati), harus berada di tempat yang tenang (contohnya di Rumah Sakit Jiwa) agar bisa dikontrol dan dirawat langsung oleh tenaga medis.

\footnotetext{
“...Kesehatan mental adalah sehat jiwa dan pikiran. Seseorang mengalami gangguan mental (gila) karena banyak pikiran. Untuk mengatasi gangguan mental berpikir tidak boleh sampai berlebihan, lebih terbuka kepada orang lain jika tidak maka akan maka bisa mengalami gangguan jiwa... "(P1)

“...Pembawaan atau turun-temurun dari nenek atau kakeknya. Bisa gangguan mental (gila) karena berpikir tidak sehat lagi/pikirannya tidak dapat dikendalikan lagi dan ciri-cirinya meliputi berbicara tidak teratur, bicara sembarangan tidak terarah. Untuk mengatasi gangguan mental maka harus berada di tempat yang tenang contohnya di RSJ jika tidak orang itu akan semakin gila ... "(P2)

“...Kesehatan mental itu jiwa kita sehat, kita bisa berpikir mana yang baik dengan tidak baik, mana yang kotor dengan bersih penyebabnya karena terlalu banyak berpikir kemudian stres selain tu ciri-cirinya meliputi terlalu banyak berpikir, berbicara sendiri,
} 
makanan sudah jatuh di jalan makan saja. Untuk mengatasi gangguan mental kita harus santai, jangan teralu banyak berpikir jika tidak maka bisa gangguan jiwa..."(P3)

“...Kesehatan mental itu tidak gila, kita bisa berpikir jenih, tahu mana yang tidak baik dan yang baik karena terlalu banyak berpikir kemudian stres dan gila dan ciri-cirinya meliputi orang yang berbicara sembaragan, makan sembarangan. Untuk mengatasi gangguan mental maka jangan berpikir berlebihan, jika ada masalah katakan jangan simpan dihati harus berbagi dengan orang lain... "( $\mathrm{P} 4)$

“...Kesehatan mental itu jiwa yang sehat, bisa berpikir secara waras, sadar dengan semua yang dilakukan penyebabnya karena terlalu banyak pikiran, ada juga karena kecewa dengan kenyataan yang ada sehingga stres dan ciri-cirinya meliputi berjalan tanpa tujuan, berbicara sembarangan, pikirannya tidak sehat lagi. Untuk mengatasi gangguan mental maka harus dibawah ke rumah sakit supaya disana bisa dikontrol dan dirawat langsung oleh tenaga medis..."(P5)

Pemahaman ini sejalan dengan pengertian sehat secara mental menurut Burhanuddin (dalam Nasilah, 2015) yakni terciptanya keharmonisan dalam jiwa dan tercapainya kesanggupan dalam menghadapi masalah setiap hari serta merasa bahagia dan puas terhadap diri sendiri. Selain itu, Aziz (2017) menyebutkan bahwa kesehatan mental dijelaskan sebagai terbentuknya keseimbangan peran kejiwaan dan adaptasi seseorang dengan diri sendiri serta lingkungan.

Dalam dimensi spiritual, partisipan mengatakan bahwa sehat meliputi kualitas relasi yang baik dengan Tuhan. Hati yang bersih melayani sesama, saling tolong menolong, saling mengasihi sesama manusia. Relasi yang baik dengan sesama adalah pengaplikasian atau wujud kualitas relasi dengan Tuhan. Untuk meningkatkan relasi dengan Tuhan dilakukan dengan cara membaca Alkitab, pergi ke gereja, berdoa dan melaksanakan perintahNya dalam hidup sehari-hari. Menurut partisipan jika relasi itu bermasalah maka hidup pasti susah, cobaan tidak ada habisnya. Untuk itu, harus berbalik dan minta ampun pada Tuhan.

“...Relasi saya baik dengan Tuhan, Wujud kualitas relasi dengan Tuhan kepada manusia/sesama adalah hati yang bersih melayani sesama, untuk meningkatkan relasi dengan Tuhan dengan cara dekatkan diri dengan Tuhan, membaca Alkitab, pergi ke gereja dan berdoa. Jika relasi itu bermasalah kita pasti mendapat banyak tantangan untuk memperbaikinya kita harus cari Tuhan, minta ampun dari Tuhan... ”(P1)

“...Kualitas relasi saya dengan Tuhan baik. Wujud kualitas relasi saya dengan Tuhan kepada manusia/sesama adalah saling tolong menolong untuk meningkatkan relasi dengan Tuhan dengan cara memuji Tuhan dan mengucap syukur kepada Tuhan karena sudah memberikan napas hidup ini secara gratis. Jika relasi itu bermasalah kita pasti mendapat banyak pencobaan oleh sebab itu kita harus berdoa pada Tuhan semoga Roh kudus menuntun kita sehingga tidak berbuat yang tidak berkenaan bagi Tuhan... ”(P2) 
“...Kualitas relasi saya dengan Tuhan baik, wujudnya saling bantu dengan orang lain untuk meningkatkan relasi dengan Tuhan dengan cara dekatkan diri kepada Tuhan. Jika relasi itu bermasalah kita akan dapat masalah, tetapi kita harus tetap cari Tuhan jangan murtat..."(P3)

“...Baik relasi saya dengan Tuhan, kita saling tolong menolong, jangan saling marah karena kata Tuhan kasihilah sesamamu manusia seperti dirimu sendiri untuk meningkatkan relasi dengan Tuhan dengan cara baca Alkitab, pergi ke gereja dan berdoa. Jika relasi itu bermasalah kita pasti susah, cobaan tidak ada habisnya. Untuk memperbaiki hubungan itu kita harus cari Tuhan dan minta ampun dari Tuhan ... "(P4)

Dalam hal ini Delgado (dalam Ardian, 2016) berpendapat bahwa manfaat dari ikatan spiritual yang dirasakan adalah: 1) Meningkatnya perasaan damai dalam diri dan batin, penerimaan yang baik terhadap kehidupan dunia, kemampuan mengatasi ketidakpastian hidup, kemampuan menerima kondisi seperti kemerosotan fisik karena usia, kondisi sakit terminal dan keadaan stress. 2) Kemampuan beradaptasi dan pemulihan kesehatan, serta upaya melalui restorasi doa dengan Tuhan sehingga diberikan kesehatan.

Sedangkan untuk dimensi ekonomi, partispan berpendapat bahwa sehat meliputi memiliki pekerjaan, penghasilan serta upaya yang dilakukan untuk menutupi kekurangan penghasilan itu. Pekerjaan partisipan berbeda-beda, ada yang bekerja sebagai petani, nelayan dan pensiunan guru. Penghasilannya per bulan bagi yang petani \pm Rp.500.000,- sampai dengan Rp.600.000,- per bulan, bagi yang nelayan per bulan \pm Rp. 1.000.000,- dan yang pensiunan guru per Rp.3.800.000 per bulan. Untuk menutupi kekurangan kebutuhan, mereka mengambil hasil kebun mereka, ada yang dijual dan ada juga yang dikonsumsi.

“...Saya bekerja sebagai petani, penghasilannya tidak pasti, tetapi per bulan bisa sampai \pm Rp.500.000,00 saya menyesuaikan pengeluaran dengan pendapatan, agar menutupi kekurangan penghasilan partisipan biasanya dengan pergi ke kebun mengambil sayur atau makanan tanah (makanan tanah meliputi umbu-umbian dan singkong) untuk dimakan..."(P1)

“...Saya pensiunan guru, penghasilan saya per bulan Rp.3.800.000 saya juga punya kebun sayur, cabe, tomat sehingga tidak perlu membeli sayur lagi...”(P2)

“...Saya seorang petani, penghasilan saya tidak pasti tapi kadang bisa mencapai $\pm R p$. 600.000,00 per bulan dan cukup untuk memenuhi kebutuhannya...”(P3)

“...Pekerjaan saya petani, penghasilan saya tidak menentu jika makanan habis terjual bisa mencapai \pm Rp. 600.000,00 dan cukup untuk memenuhi kebutuhan saya, jika membutuhkan dana tambahan saya akan mengolah tanah, menanam sayur, kacang atau 
umbi supaya sebagian dijual sebagian kita makan, walaupun tidak ada uang tapi tetap ada makanan..."(P4)

“...Pekerjaan saya itu petani dan nelayan per bulan saya bisa mendapat keuntungan \pm Rp. 1.000.000,00 dan cukup untuk memenuhi kebutuhannya. Untuk menutupi kekurangan penghasilan saya pergi mencari di laut memancing ikan dan jual untuk memenuhi kebutuhan saya dan keluarga..." (P5)

Kondisi ini sejalan dengan pengertian sehat secara ekonomi yang melingkupi upaya peningkatan kesehatan dan berhubungan dengan kesanggupan ekonomi dan tingkat penghasilan serta keadaan lingkungan sosial anggota rumah tangga (Paluhulawa, 2013). Replita (2016) dalam jurnalnya menambahkan bahwa faktor ekonomi rumah tangga sangat mempengaruhi kehidupan sosial maupun mental anggota keluarga, apabila perokonomian rumah tangga tersebut baik, maka akan dengan mudah melakukan berbagai kegiatan dalam hidup, mengingat banyaknya masyarakat yang memiliki ekonomi lemah, anak-anaknya tidak dapat dibiayainya yang membuat anaknya nakal menjadi bandel serta melawan orang tua.

3. Kesejahteraan, kepuasan hidup dan hubungan yang positif.

Dalam pemahaman partisipan, kesejahteraan adalah bentuk kasih sayang untuk keluarga, tetangga dan semua orang serta menjalani hidup dengan bahagia. Sedangkan dalam perspektif budaya setempat sejahtera berarti mempunyai makanan yang cukup, pakaian yang cukup, rumah yang cukup dan bahagia dengan semua yang dimiliki. Pemahaman diatas membuat partisipan mengidentifikasi ciri-ciri orang yang sejahtera menurut budaya adalah sebagai orang yang merasa cukup dengan semua yang dimiliki, senantiasa bersyukur, hidup aman dan tenteram serta mempunyai hubungan baik dengan semua orang. Dengan demikian sejahtera terkait dengan kepemilikan hal materi yang diimbangi dengan kualitas berinteraksi dengan sesama yang baik sehingga ada rasa syukur dan bahagia yang dialaminya.

“...Kesejahteraan adalah kasih sayang untuk keluarga, tetangga dan semua orang serta, ciri-ciri orang yang sejahtera menurut budaya di tempat ini adalah saling membantu, punya hubungan yang baik dengan semua orang... ”(P1)

“...Kesejahteraan itu adalah seorang atau warga sudah menikmati apa yang disebut kesejahteraan itu sehingga disebut sejahtera dan menjalani hidupnya dengan bahagia, Ciri-ciri orang yang sejahtera menurut budaya di tempat ini adalah orang yang merasa cukup dengan semua yang dimiliki dan bersyukur... "(P2) 
“...Kesejahteraan berarti bahagia dan bersyukur dengan apa yang kita miliki, ciricirinya adalah hidup aman dan tentram, tidak ada masalah dengan orang lain ... "(P3)

“...Kesejahteraan berarti kita merasa puas dan bahagia dengan semua yang kita miliki dan ada disekitar kita... ”(P4)

“...Kesejahteraan berarti bahagia dengan hidup kita. Ciri-ciri orang yang sejahtera menurut budaya di tempat ini adalah orang yang bersyukur dengan hidupnya... "(P5)

Pemahaman ini sejalan dengan pengertian kesejahteraan (well-being) yang disampaikan oleh Diener (dalam Utami, 2012) yang menyatakan bahwa kesejahteraan (well-being) diartikan sebagai kualitas hidup individu maupun masyarakat. Kehidupan yang baik adalah kebahagiaan (Utami, 2012). Selain itu Widyastuti (2012) juga menambahkan bahwa sejahtera merupakan keadaan dimana orang-orangnya makmur, sehat, serta damai, agar dapat mencapai kondisi tersebut diperlukan usaha sesuai dengan kemampuan yang dimiliki.

Partisipan puas dengan hidupnya saat ini karena mereka masih bisa memelihara anak-anak mereka sampai tumbuh besar, dan semua yang mereka miliki sudah cukup. Standar kepuasan dalam hidup partisipan adalah ketika anakanak sudah besar dan sudah berkeluarga, serta miliki hati yang bersih untuk melayani sesama dan keluarga.

“...Saya puas dengan hidup saya walaupun hidup susah tetapi bisa memelihara anakanak ini sampai besar dan menerima hidup saya sekarang ini karena semua sudah diatur Tuhan. Standar kepuasan dalam hidup menurut budaya di sini adalah yang penting Tuhan sudah memberikan Roh yang baik dalam diri saya sehingga saya memiliki hati yang bersih untuk melayani sesama dan keluarga..."(P1)

“...Saya puas karena semua yang saya punya cukup, makan minum, rumah, pakaian, serta menerima hidupnya sekarang ini karena semua adalah pemberian Tuhan. Standar kepuasan dalam hidup adalah anak-anak sudah besar dan sudah berkeluarga... ”(P2)

“...Puas dengan hidup saya karena walaupun susah-susah tetapi saya bisa memelihara anak-anak ini sampai besar, serta menerima hidupnya sekarang ini karena semua Tuhan sudah atur sehingga harus terima dan bersyukur. Standar kepuasan dalam hidup saya adalah yang penting anak-anak sudah besar, memiliki pekerjaan dan keluarga kecil yang baik...”(P3)

“...Saya puas dengan hidup saya karena Tuhan masih menjaga partisipan sampai saat ini dan memampukan partisipan melewati cobaan, serta menerima hidupnya sekarang ini karena semua sudah diatur Tuhan sehingga harus diterima dan bersyukur. Standar kepuasan dalam hidup saya adalah anak-anak saya sudah bekerja dan hidup dengan baik..."(P4) 
“...Saya puas dengan hidup saya karena semua yang saya punya sudah cukup. Standar kepuasan dalam hidup saya adalah anak-anak saya sudah besar dan apa yang saya miliki juga sudah cukup...”(P5)

Hal ini sejalan dengan pengertian kepuasan hidup menurut Seligman (dalam Pratama, 2015) yang menyatakan bahwa kepuasan hidup adalah suatu wujud emosi positif yang terdiri dari kesesuaian antara keinginan yang mau dipenuhi dan yang dicapai sama dengan yang diharapkan. Selain itu Linsiya (2015) juga menambahkan bahwa kepuasan hidup juga meliputi kebahagiaan, kepuasan kesehatan, pernikahan, keluarga, pekerjaan, situasi, keuangan, rasa memiliki dan kepercayaan pada orang lain.

Partisipan juga menuturkan hubungan mereka baik dengan semua orang, namun ada salah satu partisipan yang pernah dilanda konflik yakni antara istri partisipan dengan istri tetangga bertengkar/berselisih tetapi sekarang sudah damai.

“...Hubungan saya baik dengan semua orang, saya juga tidak pernah terlibat konflik dengan orang lain... ”(P1)

“...Hubungan saya baik dengan semua orang namun pernah terjadi konflik antara istri saya dengan istri tetangga adu mulut tetapi sudah damai...”(P2)

“...Hubungan kami baik, aman dan tidak pernah terjadi konflik dengan tetangga dan orang lain... ”(P3)

“...Hubungan saya baik dengan semua orang, kami saling tolong menolong, satu susah semua susah dan tidak pernah terjadi konflik...”(P4)

“...Hubungan saya baik dengan semua orang dan tidak pernah terjadi konflik... ”(P5)

Hal ini sejalan dengan pendapat Ryff (dalam Ryff dan Singer, 2008) yakni hubungan positif dengan orang lain merupakan adanya jalinan hubungan baik dengan sesama.

4. Penentuan tujuan hidup serta pengembangan potensi diri.

Dalam kategori ini, partisipan menunjukkan pemahaman bahwa tujuan hidup mereka adalah dekat dengan Tuhan, melihat anak-anak tumbuh, sukses, dan menikah dengan baik-baik. Sebagian tujuan hidup partisipan sudah tercapai. Partisipan menambahkan budaya berpengaruh terhadap tujuan hidupnya, jika lingkungannya baik maka anak-anaknya juga baik begitupula sebaliknya, terkadang orang sekitar juga menghambat pencapaian tujuan hidup partisipan seperti contoh anak partisipan sedang belajar dirumah tiba-tiba dipanggil oleh 
temannya untuk bermain, hal itulah yang mengganggu kegiatan belajarnya sehingga tidak tercapai tujuan hidupnya.

“...Tujuan hidup saya adalah dekat dengan Tuhan dan melihat anak-anaknya bekerja, sebagiannya sudah tercapai sebagiannya belum karena anak-anak ini sendiri sehingga sering saya nasehati dan berdoa untuk mereka. Saya bekerja disini bersama dengan orang-orang disini, mereka sering memberikan dukungan untuk partisipan itulah pengaruh budaya bagi saya... "(P1)

“...Tujuan hidup saya adalah melihat anak-anak partisipan tumbuh, memiliki kehidupan yang sukses, dan menikah dengan baik-baik dan syukur sudah tercapai. Pengaruh budaya bagi saya adalah terkadang orang sekitar juga menghambat pencapaian tujuan hidup saya, contohnya anak saya sedang belajar dirumah tiba-tiba dipanggil oleh temannya untuk bermain, itukan mengganggu kegiatan belajarnya... "(P2)

“...Tujuan hidup saya adalah melihat anak-anak saya bekerja dan hidup damai dengan semua orang, dan sebagian belum tercapai karena anak saya yang bungsu belum bekerja karena bulan kemarin Ia mengikuti tes TNI tetapi belum berhasil saya berdoa semoga tahun depan bisa lulus. Menurut saya budaya disini sangat berpengaruh baginya karena partisipan hidup dengan keluarga disini..."(P3)

“....Tujuan hidup saya adalah anak-anak saya bisa sukses dan jadi berkat untuk orang lain, dan sudah tercapai. Pengaruh budaya bagi saya adalah karena anak saya dibentuk di sini, jika lingkungannya baik maka anak-anaknya juga baik dan sebaliknya... ’(P4)

“...Tujuan hidup saya adalah melihat anak-anak tumbuh, memiliki kehidupan yang sukses, dan menikah dengan baik-baik, dan sebagian belum tercapai karena anak yang bungsu masih sekolah. Budaya beradampak kepada anak-anak sehingga kita harus memperhatikan anak-anak kita..."(P5)

Hal ini sejalan dengan konsep Person in Environment atau orang di lingkungan yang dikemukan dalam Putri, dkk (2015) bahwa keberadaan individu pada sebuah lingkungan akan saling mempengaruhi. Menurut Annisa, dkk (2015) Person In Environment (PIE) adalah suatu "holistic model system" yang mengenali dan mengelompokan permasalahan-permasalahan pasien/klien terhadap pengalaman-pengalamannya dengan keberfungsian social, serta assessment tentang hubungan sosial.

Tujuan hidup tidak terlepas dari potensi diri seseorang, potensi yang dimiliki partisipan adalah hati yang bersih untuk semua orang, suka bekerja dan tidak pelit. Potensi itu dikembangkan dengan cara tulus membantu sesama dan bekerja keras. Pemahaman ini sejalan dengan pengertian potensi diri menurut Yumnah (2016) yakni setiap orang memiliki kemampuan yang terpendam dalam dirinya dan memungkinkan untuk dikembangkan dengan cara berprestasi.

“...Potensi yang saya punya adalah hati yang bersih untuk semua orang dan saya mengembangkan potensin saya dengan cara tulus membantu sesama... ”(P1) 
“...Potensi yang saya miliki adalah saya orangnya suka bekerja tidak suka bermalasmalasan dan saya mengembangkan potensi saya dengan cara bekerja baik pergi ke kebun maupun mencari ikan di laut, nanti hasilnya bisa dijual dan untuk makan seharihari..."(P2)

“...Potensi yang saya punya yaitu melayani orang dan tidak kikir, saya mengembangkan potensi saya dengan cara jika ada yang kesusahan contohnya tidak ada makanan kemudian saya memiliki lebih saya akan memberi kepada orang itu... "(P3)

“...Potensi yang saya miliki adalah lebih suka memberi dari pada menerima, saya mengembangkan potensi saya dengan cara tulus membantu sesama... ”(P4)

“...Menurut saya Potensi yang saya miliki adalah saya suka bekerja, saya tidak bisa tidur-tiduran atau tetap tinggal di rumah saja, saya mengembangkan potensi saya dengan cara pergi ke kebun dan memancing di laut, hasilnya sebagian dijual sebangian dikonsumsi..."(P5)

\section{Kesimpulan dan Saran}

\section{Kesimpulan}

Sehat dan sakit kembali kepada diri individu sendiri, jika seseorang berpikir bahwa ia sakit maka ia pun akan sakit begitu pula sebaliknya. Sehat berarti didalam tubuh tidak ada penyakit dan bisa beraktifitas. Sedangkan sakit merupakan gangguan dalam tubuh, baik fisik maupun mental. Kesehatan mental merupakan sehat jiwa dan pikiran, tidak gila, bisa berpikir jenih, mengetahui mana yang tidak baik dan yang baik. Kesehatan mental juga memiliki peran dalam kesehatan seseorang, salah satunya adalah kesejahteraan (well-being). Kesejahteraan dipahami sebagai bentuk kasih sayang untuk keluarga, tetangga dan semua orang serta hidup dengan bahagia, menurut budaya setempat sejahtera berarti memiliki makanan, pakaian dan perumahan yang cukup serta bahagia dengan semua yang dimiliki.

\section{Saran}

Penelitian ini tidaklah luput dari kekurangan serta kelemahan oleh sebab itu peneliti selanjutnya diharapkan menganalisis lebih lagi tentang variabel-variabel lain yang mempengaruhi serta bagi petugas kesehatan diharapkan dapat memberikan promosi kesehatan pada masyarakat sehingga menambah pengetahuan masyarakat dalam bidang kesehatan. 


\section{DAFTAR PUSTAKA}

Ahdiah, P. (2011). Hubungan Antara Persepsi Tentang Sakit Dengan Pemanfaatan Pelayanan Kesehatan Oleh Peserta Jaminan Kesehatan Masyarakat Di Puskesmas Gunungpati Kota Semarang, 9-21. http://doi.org/Article.

Annisa, R., Wibhawa, Budhi., Apsari, C. (2016). Fenomena Remaja Punk Ditinjau Dari Konsep Person In Environment. Share Social Work Journal, 5.

Ardian, I. (2016). Konsep Spiritualitas Dan Religiusitas (Spiritual and Religion) Dalam Konteks Keperawatan Pasien Diabetes Melitus Tipe 2. Nurscope, Jurnal Keperawatan dan Pemikiran Ilmiah, 2(5), 1-9.

Aziz, R., Wahyuni, E. N., \& Wargadinata, W. (2017). Kontribusi Bersyukur dan Memaafkan dalam Mengembangkan Kesehatan Mental di Tempat Kerja. INSAN Jurnal Psikologi Dan Kesehatan Mental, 2(1), 33. http://doi.org/10.20473/jpkm.V2I12017.33-43

Budijanto, D., \& Roosihermiatie, B. (2006). Persepsi Sehat-Sakit Dan Pola Pencarian Pengobatan Masyarakat Daerah Pelabuhan (Kajian Kualitatif Di Daerah Pelabuhan Tanjung Perak). Buletin Penelitian Sistem Kesehatan, 9(2 Apr).

Chamidah, N, A. (2010). Pendidikan Inklusif Untuk Anak Dengan Kebutuhan Kesehatan Khusus. Jurnal Pendidikan Khusus 7(2).

Furqon, M., Nafiah, H. (2016). Gambaran Psychologicall Well-Being Pada Pasien Hipertensi Di Desa Wonorejo Kecamatan Wonopringgo Kabupaten Pekalongan. E-Skripsi STIKES Muhammadiyah Pekajangan.

Harjati, Thaha, R. M., \& Natsir, S. (2012). Konsep Sehat Sakit Terhadap Kesehatan Ibu Dan Anak Pada Masyarakat Suku Bajo, Kabupaten Bone, Sulawesi Selatan. E-Journal Pascasarjana Universitas Hasanuddin, (1).

Hasbullah., Nazar, M., Almasri., Meliza, R. (2014). Togak Balian: Ritual Pengobatan Masyarakat Kenegerian Koto Rajo Kuantan Singingi. Asa Riau (CV. Asa Riau).

Linsiya, R. W. (2015). Perbedaan ingkat kepuasan hidup antara mahasiswa btrata 1 (S1) dan trata 2 (S2). Psycology Forum UMM, 1(7), 284-287.

Nasilah, S., Kargenti, A., \& Marettih, E. (2015). Integrasi Diri Sebagai Konsep Sehat Mental Orang Melayu. Jurnal Psikologi, 11(1), 37-48. 
Ningrum., Cahaya, A. (2015). Analisis Pengamen Jalanan Di Kota Surakarta (Studi kasus Pengamen Jalanan di Kota Surakarta). Surakarta: Universitas Muhammadiyah Surakarta. Skripsi thesis, Universitas Muhammadiyah Surakarta.

Nurarif, H. A., Kusuma, H. (2015). Aplikasi Asuhan Keperawatan Berdasarkan Diagnosa Medis dan NANDA (North American Nursing Diagnosis Association) NIC (Nursing Intervention Classification) NOC (Nursing Outcome Classification) Jilid 2: Mediaction Jogja.

Nurfitriyana, R., \& Coralia, F. (2015). Health belief penderita hipertensi primer non compliance di Rumah Sakit Hasan Sadikin Bandung. Seminar Psikologi \& Kemanusiaan, 978-979.

Obella, Z., \& Adliyani, N. (2015). Pengaruh Perilaku Individu terhadap Hidup Sehat The Effect of Human Behavior for Healthy Life. Majority, 4(7), 109114.

Paluhulawa, I. (2013). Pengaruh Faktor Sosial Ekonomi Terhadap Status Kesehatan Masyarakat Di Kecamatan Palu. E-Jurnal Katalogis, 1(3), 1525 .

Pratama, A., Prasamtiwi, G, N., Sartika, S. (2015). Kebersyukuran Dan Kepuasan Hidup Pada Tukang Ojek. Jurnal Psikologi, 8(1).

Profil Kesehatan Provinsi Maluku Tahun 2014. (2014).

Putri, A. W., Wibhawa, B., Gutama, A. S. (2015). Kesehatan Mental Masyarakat Indonesia (Pengetahuan , Dan Keterbukaan Masyarakat Terhadap Gangguan Kesehatan Mental). Prosiding Ks: Riset \& Pkm, 2(2), 147-300.

Replita. (2016). Ekonomi Keluarga Terhadap Kesehatan Mental. 02(2), 1-16.

Kemenkes RI. (2007). Riskesdas 2007. http://doi.org/1 Desember 2013.

Kemenkes, B. P. dan P. K. (2013). Laporan Riset Kesehatan Dasar 2013, 111116. http://doi.org/10.1016/0166-0934(91)90069-C.

Ryff, C.D., Singer, B.H. (2008). Know Thyself and Become What You Are: A Eudaimonic Approach to Psychological Well-Being. Journal of Happiness Studies 9: 13-39.

Sani, N. F. (2011). Hubungan Tingkat Pengetahuan Sehat - Sakit Dengan Sikap Mahasiswa Universitas Muhammadiyah Surakarta Tentang Perilaku Hidup Bersih Dan Sehat. KesMaDasKa, 2(2), 12-18. 
Saputri, M. A. (2016). hubungan tingkat pengetahuan tentang test IVA dengan keikutsertaan wanita dalam melakukan pemeriksaannya di desa godegan mojolaban sukoharjo. Skripsi thesis, Universitas Muhammadiyah Surakarta.

Sari, F. P. (2015). Persepsi masyarakat pengguna badan penyelenggaraan jaminan sosial (BPJS) kesehatan dalam pelayanan RSUD lubuk basung kabupaten agam. Jurnal Akuntansi Dan Pajak, 2(2), 1-15.

Setiyaningsih, R., Tamtono, D., \& Suryani, N. (2016). Health Belief Model: Determinants of Hypertension Prevention Behavior in Adults at Community Health Center, Sukoharjo, Central Java. Journal of Promotion and Behavior, 1, 161-171. http://doi.org/10.26911/thejhpb.2016.01.03.03.

Sipayung, L., Kusumiati, R,. \& Ambarwati, K. (2015). Kesejahteraan Subjektif pada Remaja Awal dengan Penyakit Kanker di Rumah Sakit Kanker "Dharmais" Jakarta Barat. Program Studi Psikologi FPSI-UKSW.

Situmorang, P. (2015). Faktor - Faktor Yang Berhubungan dengan Kejadian Hipertensi pada Penderita Rawat Inap di Rumah Sakit Umum Sari Mutiara Medan Tahun 2014. Jurnal Ilmiah Keperawatan Imelda, 1(1).

Sudaryanto, A., \& Irdawati. (2008). Persepsi Lansia Terhadap Kegiatan Pembinaan Kesehatan Lansia Di Posyandu Wilayah Kerja Puskesmas Prambanan 1 Yogyakarta. Jurnal Kesehatan, 1(1), 81-90.

Sudarsono, A., Suharsono, Y. (2016). Hubungan Persepsi Terhadap Kesehatan dengan Kesadaran (Mindfulness) Menyetor Sampah Anggota Klinik Asuransi Sampah di Indonesia Medika. Jurnal Psikologi Terapan, 4(1).

Suoth, M., Bidjuni, H., Malara, R. (2014). Hubungan Gaya Hidup Dengan Kejadian Hipertensi di Puskesmas Kolongan Kecamatan Kalawat Kabupaten Minahasa Utara. E-jurnal Keperawatan, 2(1).

Utami, M. S. (2012). Religiusitas, Koping Religius, dan Kesejahteraan Subjektif, 39(1), 46-66. http://doi.org/10.1016/j.jpainsymman.2006.01.007.

Vitahealth. (2005). Hipertensi. Jakarta: PT. Gramedia Pustaka Utama.

Wibowo, S., \& Suryani, D. (2013). Pengaruh Promosi Kesehatan Metode Audio Visual dan Metode Buku Saku Terhadap Peningkatan Pengetahuan Penggunaan Monosodium Glutamat (MSG) Pada Ibu Rumah Tangga. Kesmas, 7(2), 67-74.

Widianingrum, R., \& A, H. D. (2013). Efektifitas Penyuluhan Tentang Hipertensi pada Masyarakat Rentang Usia 45-60 Tahun Dibandingkan dengan 
Masyarakat Rentang Usia 61-75 Tahun The Effectiveness of Counceling of Hypertension In The Age Range Of 45-60 Year Compared With 61-75 Year Age Range di. Jurnal Kedokteran Muhammadiyah, 1(2), 86-92.

Widiastuti. (2013). Analisis SWOT keragaman budaya Indonesia. Jurnal Widya, l(1), 8-16.

Widyastuti, A. (2012). Analisis hubungan antara produktivitas pekerja dan tingkat pendidikan pekerja terhadap kesejahteraan keluarga di jawa tengah tahun 2009. Economics Development Analysis Journal Ekonomi Pembangunan, Fakultas Ekonomi, $\quad$ UNS, $1(2), \quad 2252-6560$. http://doi.org/10.15294/EDAJ.V1I2.472.

Wongsohardjono, B, S. (2012). Kandidias Oral Pada Penderita Anemia Definisi Besi $(\mathrm{Fe})$ dan Penatalaksanaanya. Jurnal Majalah Kedokteran Gigi, XIX(1).

Yumnah, S. (2016). Kecerdasan Anak Dalam Pengenalan Potensi Diri. Jurnal Studi Islam: Pancawahana, 11(2). 